\title{
Adenoviral PSA Vaccine ETBX-071
}

National Cancer Institute

\section{Source}

National Cancer Institute. Adenoviral PSA Vaccine ETBX-071. NCI Thesaurus. Code C148142.

A cancer vaccine composed of a genetically eng ineered, replication-deficient adenovirus carrying the gene encoding human prostate-specific antigen (PSA), with potential immunostimulating and antineoplastic activities. Upon vaccination with the adenoviralPSA vaccine ET BX-071, the adenovirus infects cells and expresses PSA. In turn, PSA activates the immune system and induces a cytotoxic $T$-lymphocyte $(C T L)$ response against PSA-expressing tumor cells. PSA, a tumor associated antigen (TAA), is expressed by prostate epithelial cells and is overexpressed in prostate cancer. 